\title{
Internal Audit, Sarbanes-Oxley And Athletic Departments: An Examination And Recommendations For Reform
}

Michael D. Akers, (Email: Michael.Akers@ Marquette.edu), Marquette University Gregory Naples, (Email: Gregory.Naples@ Marquette.edu), Marquette University

\begin{abstract}
During the past fifteen to twenty years the integrity of intercollegiate athletics has been seriously questioned as a result of an increased awareness of problems associated with institutional controls over athletic departments. Limited empirical evidence has been used in the debate regarding institutional controls pertaining to the athletic department. This paper provides empirical evidence regarding the use of the internal audit function as an institutional control. Our findings indicate that while the internal audits of athletic departments are adequate, the communication of these audit results is inadequate. We also discuss the applicability of recent legislation, Sarbanes-Oxley Act of 2002, to colleges and universities. Recommendations to enhance institutional controls regarding intercollegiate athletics are provided.
\end{abstract}

\section{INTRODUCTION}

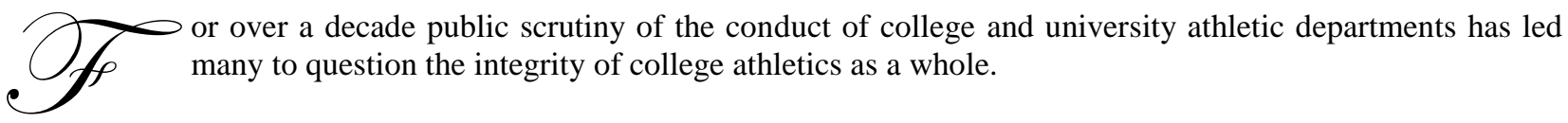

As the debate has evolved in recent years it has become increasingly evident that no one group involved in college athletics is singularly at fault for the seeming failure to successfully grapple with persistent problems such as academic fraud and the recruiting problems that we see in the media on a frequent basis. Rather what has transpired has been a gradual erosion by which all concerned parties (e.g. university presidents and boards, athletic directors and faculty) have collectively abdicated their responsibilities to the point where the ideals of intercollegiate athletics are seriously questioned by the public as well as those involved. Although done humorously, a recent Jay Leno comment illustrates how the public is mocking intercollegiate athletics, "The University of Colorado football team signed a big TV deal today. All of their games will be broadcast on Court TV next year". The perceived problems are of such a magnitude that Congress is considering examining NCAA athletics recruiting rules and regulations. The result is a need for serious discussion of intercollegiate athletics reform initiatives towards which this paper offers a three-part contribution. First, we examine the current role of the internal audit function as a tool to test and report on intercollegiate athletics department activities. This is done by updating and modifying the Akers and Naples (1993) study. Second, we provide an overview of recent legislation, Sarbanes-Oxley Act of 2002, to illustrate how concepts, that were intended to improve financial reporting for publicly traded companies, could be used by not-for- profit institutions such as colleges and universities. Third, based on the results of our study and a review of the SarbanesOxley Act of 2002 we offer specific recommendations that we believe will lead to reform in intercollegiate athletics departments.

The paper is divided into eight sections. The first section reviews literature related to internal audits of athletic departments. Section two provides a summary of audits or reviews that are currently required for intercollegiate athletics. Section three examines the role of the internal audit department with respect to the athletic 
department. The research design of our study and results are discussed in sections four and five respectively. A summary of key aspects of recent legislation, Sarbanes-Oxley Act of 2002, is discussed in section six. We offer recommendations that should enhance the monitoring and reporting of controls in the athletic department in section seven followed by our concluding comments in section eight.

\section{LITERATURE REVIEW}

Since 1981 we found only four articles (three nonempirical and one empirical) pertaining to internal audits of athletic departments. We examine the nonempirical articles first, followed by the empirical study.

Kilpatrick (1981) examined NCAA reform legislation enacted in 1985 and discussed the internal auditor's role in auditing intercollegiate athletics. She stated that the legislation required more self-regulation by institutions and that a more efficient and effective means of doing this was to have internal auditors annually audit athletic department activities. Kilpatrick concluded such audits would assist the integrity of intercollegiate athletics by providing impartial reviews of the information. Burns, Greenspan and Strawser (1995) noted that institutional conformity with NCAA regulations, requirements and rules should be addressed by a compliance audit, an audit that most internal auditors are familiar. Wells and Carrozza (2000) examined corruption in collegiate sports based on interviews with a handful of internal auditors (while they had contacted 20, only a few responded). They concluded that many athletic department frauds could have been prevented with periodic and comprehensive fraud-awareness training. Such training, however, requires time and resources that are often limited in many college and university internal audit departments.

The Akers and Naples (1993) is the only empirical study of internal audits of athletic departments that we found. They surveyed the internal auditors at institutions that were members of the Association of College and University Auditors (ACUA). They found that the majority of the respondents (75\%) perform audits of the athletic department. The findings of the study also indicated that none of the respondents were denied access to the athletic department, that the amount of time devoted to athletic department activities was adequate; and, that there were minor limitations placed on the scope of their work. The reports of such audits were distributed primarily to athletic directors followed by college/university presidents/chancellors and vice-presidents/chancellors. Akers and Naples (1993) noted the small percentage of Board of Trustees/Regents that received these internal audit reports on the athletic department was disturbing. The findings suggest that while the work of the internal auditor appears to be adequate, the communication of the audit findings was inadequate.

\section{AUDITS/REVIEWS FOR INTERCOLLEGIATE ATHLETICS}

For NCAA Division I intercollegiate athletic programs there are three reports that require either audited (external or internal) or reviewed information. Those three reports are 1. a mandatory NCAA athletics department certification self-study and peer review; 2. an annual financial audit; and 3. an Equity in Athletics Disclosure Act Report.

The NCAA requires Division I members to perform a certification self-study and peer review of its intercollegiate athletics program at least once every ten years. The process originally covered four major topical areas: 1. Governance and commitment to rules compliance, 2. Academic integrity, 3. Fiscal integrity and 4. Equity, welfare, and sportsmanship. For area one, governance and compliance, each Division I institution must have an evaluation of its rules compliance program by an appropriate individual outside of the athletic department at least once every three years. While this evaluation can be performed by a qualified person on- or off-campus, the Association of College and University Auditors (NACUBO, 2000, p. 22-30) notes that internal audit personnel are often considered the most appropriate and qualified individuals to perform the evaluation. ACUA has developed a guide to assist internal auditors in performing these audits. In January 2004 the NCAA passed legislation (http://www12.org/membership/goverance/division_I/management_council/2004/January14) that eliminated the fiscal integrity component of the self-study and peer review process. The NCAA noted that the fiscal integrity component of the self-study and peer review process was a duplication of efforts because of the required external audit of athletics departments discussed below. 
Regarding fiscal integrity, each Division I member with an athletics budget, excluding staff salaries, in excess of $\$ 300,000$ must engage an auditor, who is not a staff member of the institution to perform an annual financial audit of intercollegiate athletics activities. The guidelines for the audit were developed by the NCAA and American Institute of Internal Auditors. The audit report is delivered to the institution's CEO and is for internal use only.

The NCAA requires Division II schools with an athletics budget, excluding staff salaries, in excess of $\$ 1,000,000$ must also engage an auditor, who is not a staff member of the institution to perform a financial audit of all expenditures at least once every three years. Using the Institutional Self-Study Guide (ISSG), Division II institutions are also required to conduct a self-study and evaluation of intercollegiate athletics programs at least once every five years. Areas addressed in the report include: institutional purpose and athletics philosophy, authority of the chief executive officer in personnel and financial affairs, athletics organization and administration, finances, personnel, sports programs, recruiting policies, services, services for student-athletes and student-athlete profiles. Each institution is to make the report and supporting documentation available to the NCAA upon request (NCAA, 2003).

The Equity in Athletics Disclosure Act (EADA) of 1994 requires colleges and universities that participate in any federal financial aid program and which have an intercollegiate athletics program to report certain financial and statistical data annually. This report includes data from both the NCAA's Gender Equity Survey that is prepared by the institution's athletics department, and selected financial information from the financial audit report mentioned above. Each institution must make the report available for public inspection.

\section{ROLE OF INTERNAL AUDIT}

Management of an institution (i.e. president, vice-presidents, athletic director, compliance officer) along with governing boards having an oversight responsibility need assurances that the athletic department is both using its financial resources properly and is complying with institution and regulatory (i.e. NCAA) policies and procedures. A review of the definition of internal auditing adopted by the Institute of Internal of Internal Auditors shows that the internal audit department can be used by colleges and universities to meet these institutional objectives.

Internal auditing is an independent, objective assurance and consulting activity designed to add value and improve an organization's operations. It helps an organization accomplish its objectives by bringing a systematic, disciplined approach to evaluate and improve the effectiveness of risk management, control, and governance (Institute of Internal Auditors, 2004).

There are two key aspects of this definition that provide insight on the role of internal audit. First, independence and objectivity indicate that the internal auditor should have the freedom in both determining the scope of work and the reporting of such work. Independence and objectivity are enhanced if internal audit results are reported to a high level within the institution. The highest level for most institutions is the Board of Trustees/Regents. The second aspect pertains to value. Internal audit adds value and assists management in achieving an institution's objectives by evaluating risks, controls, and governance and by making recommendations to improve the effectiveness of each area.

There are several different types of audits, activities and services that can be provided to the athletic department by the internal audit department. These include operational audits, management advisory services, financial audits, investigative audits, compliance audits and information technology audits. 


\section{RESEARCH DESIGN}

\section{Survey Instrument}

A survey instrument similar to the instrument used by Akers and Naples (1993) was used to gather data about the current extent and coverage of internal audits of intercollegiate athletics departments. Specifically, the questions examined issues such as the internal auditor's access to the athletic department, scope limitations, types of audits performed, preparation and distribution of audit reports, the internal auditor's opinion as to who should test compliance with NCAA rules, and regulations and NCAA Athletics Department certification. A member of the research committee of ACUA reviewed the survey instrument prior to the mailing.

\section{Sample and Data Collection}

The survey instrument was mailed to 368 members of ACUA. Although the ACUA membership does not include auditors at all institutions, there is no reason to believe that the sample is not representative of internal auditors and internal audit activities pertaining to athletic departments at all universities and colleges.

\section{Analysis}

Frequencies were used to evaluate the responses of the categorical questions and the results, where appropriate were compared to the Akers and Naples (1993) findings. Although the respondents from the two studies may be different (there is no way to determine since the responses were anonymous) we believe the comparisons provide valuable insights. The responses to the open-ended questions were subjectively evaluated.

\section{RESULTS OF THE STUDY}

\section{Response Rate/Demographics}

A total of 81 responses were received resulting in a response rate of $22 \%$. Table 1 below shows the demographic data for both the respondents' institutions and internal audit departments.

\begin{tabular}{|l|c|c|}
\hline \multicolumn{2}{|c|}{ Table 1 } \\
\hline & \multicolumn{2}{c|}{ Demographic Data } \\
\hline Institutional: & Current & $\mathbf{1 9 9 3 ~ S t u d y ~}$ \\
\cline { 2 - 3 } Student enrollment (full-time equivalent) & 15,157 & 15,212 \\
Total operating budget of college/university & $\$ 464,239,042$ & $\$ 243,371,757$ \\
Total operating budget of internal audit department & $\$ 289,027$ & $\$ 235,334$ \\
Total operating budget of athletic department & $\$ 9,532,150$ & $\$ 3,932,070$ \\
\hline Internal Audit Department: & & \\
Number of professional personnel & 4.4 individuals & 4.7 individuals \\
Number of years director of internal audit has served in that capacity & 7.1 years & 5.88 years \\
Number of years director has been associated with the internal audit department & 8.4 years & 6.98 years \\
\hline Professional certifications: & & \\
Certified Public Accountant & $40 \%$ & $54 \%$ \\
Certified Internal Auditor & $9 \%$ & $10 \%$ \\
Certified Management Accountant & $2 \%$ & $2 \%$ \\
Certified Fraud Examiner & $0 \%$ & $0 \%$ \\
Other & $3 \%$ & $10 \%$ \\
Multiple Certifications & $\underline{46 \%}$ & $\underline{24 \%}$ \\
$\quad$ Total & $\underline{100 \%}$ & $100 \%$ \\
\hline
\end{tabular}

Several interesting observations can be drawn from the demographic data. While the enrollment of the respondents of both studies is essentially the same, the operating budget of the universities in the current study is 
almost twice the operating budgets of those institutions that participated in the 1993 study. Athletic department budgets are approximately $238 \%$ greater than the 1993 budgets, yet internal audit budgets have only increased by approximately 23\%. USA Today (February 18, 2004) reported that between 1995 and 2001 spending by Division I intercollegiate athletic programs increased by $25 \%$, adjusted for inflation, as compared to an increase in university spending of $1 \%$ (also adjusted for inflation). The number of professional personnel in internal audit is down slightly while the length of tenure by the director in that capacity, and with the university, has increased slightly. The types of professional certifications of the respondents are similar with one exception; a greater number of the respondents in the current study have multiple certifications as compared to the 1993 study. Almost all of the respondents with multiple credentials include the CPA designation and some also have the CFE certification. While the percentages (professional certifications) shown in Table 1 are based on those that reported a professional certification, please note that in the current study there were approximately $13 \%$ that did not report any professional certification. The prior study (Akers and Naples 1993) did not disclose the number professionals without any certifications.

Table 2 below shows the status (i.e., NCAA, NAIA) of the athletic department of the respondents.

\begin{tabular}{|l|c|c|}
\hline \multicolumn{2}{|c|}{ Table 2 } & Current \\
\hline Status of Athletic Department & $66 \%$ & $\mathbf{1 9 9 3}$ \\
\hline NCAA Division I & $15 \%$ & $59 \%$ \\
\hline NCAA Division II & $12 \%$ & $9 \%$ \\
\hline NCAA Division III & $1 \%$ & $10 \%$ \\
\hline NAIA & $1 \%$ & $4 \%$ \\
\hline Other (i.e. junior college) & $5 \%$ & $3 \%$ \\
\hline Multiple categories* & & $15 \%$ \\
\hline $\begin{array}{l}* \text { Note: Some universities participate at one level for some sports and at } \\
\text { another level for other sports. }\end{array}$ & \\
\hline
\end{tabular}

Consistent with the prior study, the majority of the respondents participate at the Division I level. Most of the schools that participate at multiple levels have at least one sport where they participate at the Division I level. When these multiple-level schools are considered, $70 \%$ participate at the Division I level as compared to $71 \%$ in the 1993 study.

\section{Performance of Annual Audits}

The institution (Board, President/Chancellor, and internal audit department) must asses the risks associated with the intercollegiate athletics department to determine whether an annual internal audit of the department is necessary. Our results show that $93 \%$ of the institutions perform an annual audit. This represents approximately a $20 \%$ increase from our prior study as $75 \%$ of the respondents in 1993 conducted annual audits of the athletic department. While we can only speculate as to the reasons for the increased number of institutions performing audits of the athletics department, two possible explanations are the NCAA certification process and increased public scrutiny.

\section{Access and Scope Limitations}

To appropriately serve as a control mechanism, internal auditors should have access to all records within the athletic department and there should not be any restrictions on the procedures performed. Our findings show that only 2.5\% (as compared to 0\% in the 1993 study) of the respondents had been denied any access to the athletic department and "none" (as compared to less than 5\% in the prior study) of the respondents having access had any limitations placed on the work performed. 


\section{Types of Audits and Hours Utilized}

The respondents were asked to indicate if they performed any of four specific types of audits (1. financialrevenues/expenses 2. compliance-internal controls 3. compliance-NCAA rules and regulations 4. operational-testing efficient and effective use of resources) and to indicate the number of hours devoted to each type of audit. Table 3 below shows the results along with a comparison of the 1993 findings.

\begin{tabular}{|l|c|c|c|c|}
\hline \multicolumn{5}{|c|}{ Table 3 } \\
\hline Types of Audits and Hours Utilized & Current Study & Current Study & 1993 Study & 1993 Study \\
\hline Type & $\begin{array}{c}\text { Percentage of } \\
\text { Respondents } \\
\text { Performing Audit }\end{array}$ & $\begin{array}{c}\text { Average Hours } \\
\text { Utilized }\end{array}$ & $\begin{array}{c}\text { Percentage of } \\
\text { Respondents } \\
\text { Performing Audit }\end{array}$ & $\begin{array}{c}\text { Average Hours } \\
\text { Utilized }\end{array}$ \\
\hline Financial (revenues/expenses) & $69 \%$ & 123 & $48 \%$ & 153 \\
\hline Compliance (internal controls) & $62 \%$ & 119 & $56 \%$ & 144 \\
\hline Compliance (NCAA rules/regulations) & $49 \%$ & 219 & $39 \%$ & 157 \\
\hline $\begin{array}{l}\text { Operational (effective and efficient } \\
\text { use of resources) }\end{array}$ & $44 \%$ & 133 & $34 \%$ & 158 \\
\hline
\end{tabular}

When compared to the findings of the previous study, the results show that the number of respondents performing each type of audit has increased with the greatest increase in the financial (revenues/expenses) audit. Interestingly, while there has been an increase in the percentage of respondents performing the various types of audits, the number of hours devoted to each audit, except one (compliance with NCAA rules and regulations), has decreased. The increase in the number of hours devoted to audits related to compliance with NCAA rules and regulations is almost $40 \%$. In order to determine if a certain percentage of the total operating budget were allocated to the athletic department, and whether a similar percentage of internal audit personnel hours would also be allocated, we performed the same analysis as we did in 1993. We used time (audit hours) and budget information. The percentage of audit time devoted to athletic department audits was developed by comparing the total hours expended for athletic department audits to the total hours expended for all college and university audit work. Similarly, a budget percentage was developed by comparing the athletic budget with the total operating budget of the college or university. Table 4 below shows the analysis.

\begin{tabular}{|c|c|}
\hline \multicolumn{2}{|l|}{ Table 4} \\
\hline Analysis of Time Devoted to Athletic Department Audits & \\
\hline Estimated hours used for athletic department audits & $594 *$ \\
\hline Estimated total hours internal audit & $6,864^{\wedge}$ \\
\hline Estimated percent of time devoted athletic department audits & $8.65 \%$ \\
\hline Athletic department budget/total budget-see Table 1 & $2.05 \%$ \\
\hline$*$ Total represents the sum of hours listed in Table 3 above $(123+119+219+133)$ & \\
\hline $\begin{array}{l}\text { ^Calculated as follows: average size of internal audit department ( } 4.4 \text { individuals) } * 2080 \text { hours ( } 40 \text { hours } \\
\text { per week } * 52 \text { weeks) } * 75 \% \text { (estimated productive time based discussions with internal auditors) }\end{array}$ & \\
\hline
\end{tabular}

The results show that the percentage of time (8.5\%) devoted to athletic department audits is greater than the percentage $(2.05 \%)$ of the college/university budget dollars allocated to the athletic department. These findings are consistent with our prior findings and suggest that the time devoted to internal audits of athletic departments is adequate. Possible explanations as to why a greater amount of time is devoted to these audits than prior expectations, using budgeted financial information, include: public scrutiny, possibility of adverse publicity, operating costs are greater in the athletic department than other units of the university where payroll costs are more significant, and the need to obtain or maintain the NCAA Athletics certification. 


\section{Audit Reports}

Regarding the audit work performed, $97 \%$ of the respondents indicated they generated a report. This result is not surprising and is the same as our prior study where we found $97 \%$ of the respondents generated a report. Unfortunately the results of this study, regarding the distribution of audit reports, are also similar to our prior study results. Table 5 below shows the results.

\begin{tabular}{|l|c|c|}
\hline \multicolumn{2}{|c|}{ Table 5 } \\
\hline Distribution of Audit Report & Current Study & 1993 Study \\
\hline Athletic Director & $80 \%$ & $95 \%$ \\
\hline College/University President/Chancellor & $75 \%$ & $82 \%$ \\
\hline Board of Trustees/Regents & $44 \%$ & $45 \%$ \\
\hline
\end{tabular}

Athletic directors are still receiving the audit report more frequently than presidents/chancellors although the gap is not as large as it was in 1993. The percentage of Boards that are receiving these reports is essentially the same and once again raises the question of the internal auditor's reporting independence. To enhance the independence of the internal audit function, these reports need to be distributed to those individuals (Boards/Trustees) that have an oversight responsibility. This finding is particularly alarming considering the attention directed toward Boards over the past ten years by the corporate sector, Congress and regulatory bodies such as the Securities and Exchange Commission. Also, recent internal auditing literature (Hughes, 2004; Robitaille, 2004) includes among the Best Practices of an internal audit department reporting and communicating to the Board.

\section{Follow-Up of Reported Problems}

The respondents were also asked if there were situations where the audit identified and reported problems, yet corrective action was not taken. Similar to the prior study, we found that $14 \%$ of the respondents stated that there were such situations. For those situations where no corrective action was taken, the respondents did not indicate any serious unresolved issues but rather a disagreement between the internal auditor and the athletic director, manager of the athletics department.

\section{Testing Compliance with NCAA Rules and Regulations}

The respondents were asked to indicate who they thought should be testing for compliance with NCAA rules/regulations and why. The group most frequently cited by the respondents was internal auditors (40\% of respondents), followed by a combination of both external and internal auditors (17\%), compliance officer (15\%), external auditors (13\%), athletic department personnel (10\%) and the NCAA $(5 \%)$. These results suggest that the majority (at least $78 \%$ or more, if the combination group is considered) of the respondents believe this testing should be done internally. This viewpoint by the respondents, along with the low frequency that the NCAA was cited is consistent with the NCAA's position that institutions should have the responsibility for compliance, not the NCAA (Akers and Naples, 1993). It is interesting to note that the respondents cited internal auditors more frequently in this study as compared to the prior study and cited external auditors and NCAA personnel less frequently. While the reasons provided by the respondents as to who should perform the testing of compliance with NCAA rules and regulations varied, three primary issues emerged: 1. Need for independence and objectivity (lack of conflict of interest); 2. Need for expertise with regard to NCAA rules and regulations, and, the University's policies and procedures; and, 3. Need to use resources effectively and efficiently (in consideration of the cost-benefit relationship of such testing). Each institution should consider these issues in determining who will perform the compliance tests of NCAA rules and regulations. 


\section{NCAA Athletics Certification}

The NCAA Athletics Certification was in its infancy stages in 1993; accordingly, we did not examine this issue in our prior study. Since the certification process forces Division I institutions to review financial and operational controls in the athletics department, we asked the respondents to indicate if their institution's athletics department had received this certification. The findings of our current study show that $78 \%$ of the respondents had received the NCAA Athletics Certification, $2 \%$ had not and for $20 \%$ it was not applicable. Considering the percentage of schools that compete at the Division I level (See Table 2), these findings suggest that some schools that do not compete at this level are also obtaining this certification. We also believe that the large percentage of schools with this certification is consistent with the increase in the percentage of internal audit departments performing internal audits of athletic departments (See Table 3).

\section{SARBANES-OXLEY ACT OF 2002}

President Bush signed into law on July 30, 2002 the Sarbanes-Oxley Act of 2002. The intent of the law was bolster confidence in our nation's capital markets and to impose new duties and penalties for regulatory noncompliance on public companies and their directors, executives, auditors, attorneys and financial analysts. While the Act is not applicable to private and not for profit organizations, we believe some of the major provisions are appropriate for colleges and universities. Those provisions include:

- The Audit Committee shall be responsible for the appointment, compensation and oversight of the work of the external public accounting firm.

- $\quad$ Each member of the Audit Committee shall be independent and a member of the Board of Directors

- $\quad$ Entity must disclose if at least one member of the audit committee is a financial expert, as defined by the legislation

- $\quad$ The CEO and CFO must issue a statement to accompany the periodic financial report to certify the appropriateness of the financial statements and related disclosures.

- $\quad$ The CEO and CFO must issue a statement to accompany the periodic financial report to certify that internal controls have been reviewed for their effectiveness

- $\quad$ Requires the annual report to include an assessment of the effectiveness of the entity's internal controls and procedures used for financial reporting.

- $\quad$ Entities are required to disclose whether it has adopted a code of ethics for its senior financial officers.

These provisions primarily focus on organizational control and corporate governance. Although some would advocate engrafting Sarbanes-Oxley into the governance structure of non-profit institutions such as colleges and universities, it might be more reasonably effective to take notice of some of the Sarbanes principles to demand that governing boards establish sufficient internal controls to more effectively manage intercollegiate athletics programs. Many public and private institutions, whether by state law or choice, have already moved in the direction of better board level controls. For example, Attorney General Eliot Spitzer of New York has proposed requirements for nonprofits that are similar to those in the Sarbanes-Oxley Act of 2002 (Larkin, 2004). We believe the failure of college and university governing boards to exercise regular and informed stewardship; to effectively adopt and implement organizational controls; and, to more effectively exercise their governance prerogatives, is also a factor to a loss of institutional control. Concerning matters of intercollegiate athletics, if boards do not effectively adopt policies and procedures to integrate intercollegiate athletics into the mission of the academy with a clearly articulated rationale for participation and financial support, then the institutional debate on assessment and resource allocation can never become transparent. 


\section{RECOMMENDATIONS TO ENHANCE INSTITUTIONAL CONTROLS RELATED TO THE ATHLETIC DEPARTMENT}

Based on the findings of our study and a review of recent legislation (Sarbanes Oxley), we offer the following recommendations that we believe will enhance the monitoring and reporting of athletic department controls:

- The NCAA should consider legislation that mandates the reduction of expenditures associated with intercollegiate athletics. The findings of this study show that since 1993 university/college operating budgets increased by approximately $90 \%$ while athletic department budgets increased by almost $240 \%$.

- $\quad$ All internal audit reports of the athletic department should be distributed to the Board of Trustees/Regents and the Audit Committee, if such a committee exists.

- College and university presidents/chancellors should certify, by attested signature, the accuracy and comprehensiveness of all financial disclosures related to intercollegiate athletics at their institution. Such certification would pertain to all sources of revenue and expense used to support the intercollegiate athletics program whether internally generated or directly, or indirectly, provided by third parties (Sections 302 and 401 (a), Sarbanes-Oxley Act of 2002).

- $\quad$ College and university presidents/chancellors should certify, by attested signature, as to the design and effectiveness of internal controls related to both financial and nonfinancial (such as compliance, diversity and gender equity) items (Section 404, Sarbanes-Oxley Act of 2002).

- Colleges and universities engaged in intercollegiate athletics, at whatever Division or level, should have a board/trustee Audit Committee comprised of three financially literate members. At least one of the three should meet the criteria of a financial expert as defined by the Sarbanes-Oxley Act of 2002. At least one of the three needs to be generally familiar with matters of intercollegiate athletics. In order to avoid any conflicts of interest, all Committee members must be wholly independent of any direct or indirect financial dealings with the institution.

- $\quad$ The Audit Committee should be a free-standing, permanent committee of the Board/Trustees charged with the ultimate oversight responsibility for all financial and non-financial (such as compliance) operations and reporting.

- $\quad$ The Audit Committee should have access to all internally or externally generated contracts, reports, or filings related to the institution's intercollegiate athletics program.

- $\quad$ The Audit Committee should have the responsibility to hire and terminate the external auditor and should approve all nonattest services prior to the engagement (Sections 203, 204, 301 and 407, Sarbanes-Oxley Act of 2002).

- $\quad$ All colleges and universities engaged in intercollegiate athletics having total revenue (as reported at line 12 of the institution's most recent Form 990) of $\$ 50,000,000$ or more should have an internal auditor. This recommendation is similar to the requirement for an internal audit function adopted by the Securities and Exchange Commission, New York Stock Exchange and the National Association of Security Dealers Automated Quotations (Institute of Internal Auditors, 2004).

- All institutions engaged in intercollegiate athletics should adopt a code of ethics for its senior officers, athletic directors and coaches that would go beyond the general provisions of a conflict of interest policy. A code might address issues such as institutional prerequisites, financial support sourcing and prohibited personal conduct as these items relate to the athletic program.

\section{CONCLUSION}

While there has been considerable media scrutiny regarding the lack of institutional controls over intercollegiate athletics, limited attention has been directed toward the use of the internal audit function as an institutional control tool. Our study examined this issue and we offer the following conclusions:

- $\quad$ Athletic department budgets have increased by a much larger percentage than the operating budgets of institutions since 1993.

- $\quad$ The number of institutions performing internal audits of the athletic department has increased since 1993. 
- The amount of time utilized for the different types of audits has decreased since 1993, with one the exception-testing of compliance with NCAA rules and regulations.

- Access to athletic department evidence has not been denied and scope of audit procedures has not been restricted.

- Reporting of audit results is inadequate as the athletic director receives the audit results more frequently than the Board of Trustees/Regents and the President. Accordingly, the independence of the internal audit department can be questioned. The Board must receive these reports more frequently if the Board is going to adequately perform its oversight role.

Although the Sarbanes-Oxley Act of 2002 was designed for public companies, several of the requirements pertaining to the role of the audit committee as well as the CEO and CFO are just as applicable to not for profit organizations. We believe the implementation of these requirements by universities are cost-beneficial and will enhance institutional controls over athletic departments.

Acknowledgement: The authors would like to thank Anton Baumann for his assistance in collecting the data and we also appreciate the information and input provided by the Association of College and University Auditors.

\section{REFERENCES}

1. Akers, Michael D. and Gregory J. Naples, 1993. "An Analysis of Internal Audits of Athletic Departments". Internal Auditing. Vol. 8, No. 3 (Winter) pp. 53-62.

2. Burns, David C., Greenspan, James W., and Strawser, Robert H., 1995. "Auditing in Intercollegiate Athletics Arena". Internal Auditor. December. pp. 46-49.

3. http://www12.ncaa.org/membership/goverance/division_I/managent_council/2004/January. Report of the NCAA Division I Committee on Athletics Certification.

4. $\quad$ Hughes, Peter, 2004. "Why Internal Auditors Audit". The CPA Journal. February. pp. 15-16.

5. Institute of Internal of Auditors, 2004. "New Governance Rules Require Internal Auditing". Tone at the Top. Issue 21. (February). pp. 1-2.

6. Institute of Internal Auditors, 2004. "Professional Practices Framework". Altamonte Springs, FL. Institute of Internal Auditors.

7. Kilpatrick, J.C., 1987. "Performing Internal Audits of Intercollegiate Athletics: A Self-Monitoring Tool”. The Woman CPA. July. pp. 13-17.

8. Larkin, Richard, 2004. "Sarbanes-Oxley's impact on nonprofits". The Wisconsin CPA., Vol. 8, No. 3. (March). p. 9.

9. National Association of College and University Business Officers, 2000. "College \& Business Administration". Sixth Edition. Washington, D. C.

10. National Collegiate Athletic Association, 2003. “2003-04 NCAA Division II Manual”. Indianapolis, Indiana. The National Collegiate Athletic Association.

11. Robitaille, Donald B., 2004. "World-class Audit and Control Practices". Internal Auditor. February. pp. 7481.

12. Sarbanes-Oxley Act of 2002 (Public Law 107-204).

13. USA Today, February 18, 2004. "Athletic spending grows as academic funds dry up". pp. 1A-2A.

14. Wells, Joseph T. and Richard B. Carozza, 2000. "Corruption in Collegiate Sports". Internal Auditor. April. pp. 46-51. 